\title{
ISOLATION AND CHARACTERIZATION OF TWO PLANT GROWTH-PROMOTING BACTERIA FROM THE RHIZOPLANE OF A LEGUME (Lupinus albescens) IN SANDY SOIL ${ }^{(1)}$
}

\author{
Adriana Giongo ${ }^{(2)}$, Anelise Beneduzi ${ }^{(2)}$, Adriana Ambrosini ${ }^{(2)}$, \\ Luciano Kayser Vargas ${ }^{(3)}$, Marcos Roberto Stroschein ${ }^{(4)}$, Flávio Luiz \\ Eltz $^{(4)}$, Maria Helena Bodanese-Zanettini ${ }^{(2)}$ \& Luciane Maria Pereira \\ Passaglia $^{(2)}$
}

\section{SUMMARY}

Two bacterial strains that amplified part of the nifH gene, RP1p and RP2p, belonging to the genus Enterobacter and Serratia, were isolated from the rhizoplane of Lupinus albescens. These bacteria are Gram-negative, rod-shaped, motile, facultative anaerobic, and fast-growing; the colonies reach diameters of 3-4 mm within $24 \mathrm{~h}$ of incubation at $28^{\circ} \mathrm{C}$. The bacteria were also able to grow at temperatures as high as $40{ }^{\circ} \mathrm{C}$, in the presence of high $(2-3 \% \mathrm{w} / \mathrm{v}) \mathrm{NaCl}$ concentrations and $\mathrm{pH} 4-10$. Strain RP1p was able to utilize 10 of $14 \mathrm{C}$ sources, while RP2p utilized nine. The isolates produced siderophores and indolic compounds, but none of them was able to solubilize phosphate. Inoculation of $L$. albescens with RP1p and RP2p strains resulted in a significant increase in plant dry matter, indicating the plant-growth-promoting abilities of these bacteria.

Index terms: indolic compounds, siderophores, inoculation experiment.

\footnotetext{
(1) Recebido para publicação em setembro de 2008 e aprovado em janeiro de 2010.

${ }^{(2)}$ Departamento de Genética, Instituto de Biociências, Universidade Federal do Rio Grande do Sul - UFRGS. Av. Bento Gonçalves 9500, Caixa Postal 15053, CEP 91501-970 Porto Alegre (RS), E-mails: adriana_giongo@yahoo.com.br; abeneduzi@yahoo.com.br; adri_ambrosini@yahoo.com.br; maria.zanettini@ufrgs.br; lpassaglia@terra.com.br

(3) Fundação Estadual de Pesquisa Agropecuária - FEPAGRO. Rua Gonçalves Dias 570, CEP 90130-060 Porto Alegre (RS). Email: luciano-kayser@fepagro.rs.gov.br

(4) Departamento de Ciência do Solo, Faculdade de Agronomia, Universidade Federal de Santa Maria - UFSM. Av. Roraima 1000, Camobi, CEP 97105-900 Santa Maria (RS). E-mails: marcosstroschein@yahoo.com.br; feltz@ccr.ufsm.br
} 


\title{
RESUMO: ISOLAMENTO E CARACTERIZAÇÃO DE DUAS BACTÉRIAS PROMOTORAS DE CRESCIMENTO VEGETAL DO RIZOPLANO DE UMA LEGUMINOSA (Lupinus albescens) DE SOLO ARENOSO
}

\begin{abstract}
Duas linhagens bacterianas que apresentaram amplificação de parte do gene nifH, $R P 1 p$ e RP2p, pertencentes aos gêneros Enterobacter e Serratia, foram isoladas do rizoplano de Lupinus albescens. Essas bactérias são Gram-negativas, com formato de bastonete, móveis, anaeróbias facultativas e apresentam multiplicação rápida, com colônias alcançando diâmetros de 3-4 mm em 24 h de incubação a $28{ }^{\circ} \mathrm{C}$. RP1p e RP2p também foram capazes de multiplicação em temperaturas elevadas, como $40{ }^{\circ} \mathrm{C}$, na presença de alta concentração de $\mathrm{NaCl}(2-3 \% \mathrm{v} / \mathrm{v})$ e em valores de $\mathrm{pH}$ que variaram de 4 a 10. A linhagem RP1p foi capaz de utilizar 10 das 14 fontes de carbono avaliadas, enquanto a linhagem RP2p utilizou nove. Os isolados produziram sideróforos e compostos indólicos, mas foram incapazes de solubilizar fosfatos. A inoculação de L. albescens com as linhagens RP1p e RP2p resultou em aumento significativo do peso das plantas secas, o que demonstra que essas bactérias apresentam propriedades que favorecem o crescimento vegetal.
\end{abstract}

Termos de indexação: compostos indólicos, sideróforos, experimentos de inoculação.

\section{INTRODUCTION}

It is widely accepted that rhizosphere and rhizoplane microorganisms can influence plant growth and development. The term plant growth-promoting rhizobacteria (PGPR) was coined for the bacterial biocontrol agents of the rhizosphere (Kloepper et al., 1980). Some years later, the term plant growthpromoting bacteria (PGPB) was proposed to designate rhizobacteria that enhance plant growth by other ways (Bashan \& Holguin, 1998). Plant growth-promoting (PGP) activities have been reported for a series of bacterial species including Pseudomonas, Azospirillum, Azotobacter, Klebsiella, Enterobacter, Alcaligens, Arthobacter, Burkholderia, Bacillus and Serratia (Versalovic et al., 1994; Glick, 1995; Han et al., 2005). Although the mechanisms by which PGPB promote plant growth are not fully understood (Glick, 1995; Ahmad et al., 2008), these bacteria can improve plant growth by $\mathrm{N}_{2}$ fixation, phytohormone and siderophore production, phosphorus solubilization, and disease control (Bashan \& Holguin, 1998; Barea et al., 2005). Moreover, the root-surrounding environment, the rhizosphere, is a dynamic soil site of nutrient turnover. Bacteria around plant roots perform a wide range of metabolic activities and are able to make use of a wide range of low molecular mass organic compounds and of some more complex compounds as C and energy sources (Misko \& Germida, 2002). These microorganisms play major roles in nutrient transformation and element cycling and influence the availability of these nutrients for plant uptake (Dunfield \& Germida, 2001).

The family Leguminosae comprises about 750 genera and more than 18,000 species, from which only
$8 \%$ are cultivated plants. Little information is available on wild legumes and their root-associated bacteria. These interactions are particularly important when they result in tolerance to extreme environmental conditions such as severe drought, elevated temperature and salinity (Moschetti et al., 2005). High tolerance to extreme abiotic situations is very important in some regions of Rio Grande do Sul (RS), Brazil, where about $5.2 \%$ of the soils are sandy and acid, which is characteristic of subtropical arid climates (Schumacher, 2000). Lupinus albescens H. et Arn, an indigenous leguminous species, has been used in the recovery of these sandy soils due to its high rusticity, strong adaptability to sandy regions, ability to reduce the eolic erosion process, upgrade dry matter, improve the soil quality and cover, and the capacity of biological $\mathrm{N}_{2}$ fixation when establishing symbiosis with some bacteria belonging to the genus Bradyrhizobium, as identified by sequencing of the ITS region of strains obtained by Stroschein (2007).

So far, no study has described or selected PGPB associated to $L$. albescens plants. Moreover, a better knowledge of these bacteria and their implications on plant physiology could change traditional crop management practices regarding plant nutrition and defense mechanisms. For a maximum exploitation of the plant-bacteria association, effective bacteria must be selected in plant studies that take specific ecological conditions into consideration, e.g., crop management, soil, temperature, etc. The primary aim of this study was to isolate and characterize rhizoplane bacteria associated with native Lupinus albescens H. et Arn. grown in sandy soils of RS. These bacteria may help their host plant to support adverse ecological conditions due to their PGP characteristics. 


\section{MATERIALS AND METHODS}

\section{Collection site and soil sampling}

Small root pieces from Lupinus albescens $\mathrm{H}$. et Arn. were collected from an experimental field $\left(29^{\circ} 39^{\prime} 58^{\prime} \mathrm{S}, 55^{\circ} 23^{\prime} 43^{\prime} \mathrm{W}\right)$, in Alegrete, Rio Grande do Sul, Brazil. The regional climate is classified as Cfa according to Köppen, humid subtropical, no dry season, with an annual rainfall of about 1,400 mm (Souto, 1984). The area under study had never been inoculated with commercial bacterial inoculants but underwent some degradation processes, as huge sandy spots indicate.

\section{Bacteria isolation and reference strains}

Bacteria from the rhizoplane of $L$. albescens were isolated in yeast-mannitol agar (YMA) medium by standard procedures (Fred \& Waksman, 1928). The bacteria were purified by repeated streaking and the pure cultures stored at $-10{ }^{\circ} \mathrm{C}$, in $30 \%$ glycerol-yeast mannitol broth. Two rhizobial reference strains (Bradyrhizobium sp. SEMIA 928 and SEMIA 938), from the Biological Nitrogen Fixation Center, Fepagro, Brazil, and three other bacteria (Enterobacter sp., Pseudomonas sp., and Klebsiella sp.) available in the laboratory were used as control. To confirm their purity, all isolates and control strains were streaked on YMA medium plus $25 \mathrm{mg} \mathrm{mL}^{-1}$ Congo red dye and on glucose-peptone agar (GPA) medium plus $100 \mathrm{mg} \mathrm{mL}^{-1}$ bromothymol blue (Fred \& Waksman, 1928), as $\mathrm{pH}$ indicator.

\section{Phenotypic characterization}

\section{Morphology, motility and electron microscopy}

The cell morphology was examined by phasecontrast microscopy and the spore types under a scanning electron microscope in cells from $48 \mathrm{~h}$ cultures in YMA medium. Cells were fixed according to Borges et al. (2004) and the grids examined by a scanning electron microscope (model XL-30, Philips). Gram staining was performed (Doetsch, 1981) and motility verified by the SIM (Hydrogen-Sulfide, Indole, Motility; Mac Faddin, 2000) test.

\section{Growth rates}

The bacterial colony size was determined on YMA after $48 \mathrm{~h}$ at $28^{\circ} \mathrm{C}$. The strains were grown in YMA plates and categorized as very fast (colonies visible in less than one day), fast (colonies visible in 2-3 days) and slow-growing (colonies visible in $3-5$ days) (Somasegaran \& Hoben, 1992).

\section{Carbohydrate utilization}

Different groups of $\mathrm{C}$ sources were evaluated: monosaccharides (L-arabinose, D-fructose, D- galactose, D-glucose, D-mannose, rhamnose, and Dxylose), disaccharides (lactose, maltose, and sucrose) and sugar alcohol (glycerol, inositol, mannitol, and sorbitol). The basal medium used for $\mathrm{C}$ assimilation was a minimum salt medium (MSM, Brown \& Dilworth, 1975). Carbon sources were sterilized by filtration (pore size $0.45 \mu \mathrm{m}$, Millipore) and added aseptically to the autoclaved MSM at a final concentration of $1 \mathrm{~g} \mathrm{~L}^{-1}$. The medium contained $2 \mathrm{~mL}$ of $0.5 \%$ phenol red per liter as $\mathrm{pH}$ indicator. About $50 \mu \mathrm{L}$ of culture of each bacterium grown in YEM broth for $48 \mathrm{~h}$ at $28^{\circ} \mathrm{C}$ was filled into an individual culture tube containing MSM and the designed carbon source and left to grow at $128 \mathrm{rpm}$ at $28^{\circ} \mathrm{C}$. After $72 \mathrm{~h}$, the bacteria that were able to grow in a given $\mathrm{C}$ source modified the $\mathrm{pH}$ of the medium, turning it from red to yellow. This behavior was recorded as growth (+) or no growth (-) in comparison with controls. All experiments were performed in triplicate.

\section{Salt, pH and temperature tolerance}

Salt tolerance was evaluated using $0.5,1,2,3$, or $4 \%(\mathrm{w} / \mathrm{v}) \mathrm{NaCl}$ in YEM broth. The $\mathrm{pH}$ tolerance was evaluated using YEM broth with $\mathrm{pH}$ ranging between 4 and 10 (Solano et al., 2006). About $50 \mu \mathrm{L}$ of culture of each isolate grown in YEM broth for $48 \mathrm{~h}$ at $28^{\circ} \mathrm{C}$ were was filled into individual tubes containing the different $\mathrm{pH}$ or $\mathrm{NaCl}$ concentration and left to grow at $128 \mathrm{rpm}$. The growth (+) or no growth (-) in comparison with the controls after $72 \mathrm{~h}$ was recorded. The temperature tolerance of isolates was tested at 28 (control), 37 and $40{ }^{\circ} \mathrm{C}$ on YMA for two days. All tests were carried out in triplicate.

\section{Siderophore production}

Bacterial samples were evaluated for their capacity of siderophore production in Petri dishes containing King B medium supplemented with a complex chrome azurol S [CAS/iron(III)/ hexadecyl trimethyl ammonium bromide] as described by Schwyn \& Neilands (1987). Bacteria that were able to produce siderophores grew and formed a yellow halo in the blue-green media.

\section{Phosphate solubilization}

The method described by Sylvester-Bradley et al. (1982) was used to identify isolates able to solubilize phosphates. Bacteria were grown in glucose yeast medium (GL) containing $10 \mathrm{~g}$ glucose, $2 \mathrm{~g}$ yeast extract and $15 \mathrm{~g}$ agar per liter. Two other solutions were prepared separately, one containing $5 \mathrm{~g} \mathrm{~K}_{2} \mathrm{HPO}_{4}$ in $50 \mathrm{~mL}$ distilled water, and the other containing $10 \mathrm{~g} \mathrm{CaCl}_{2}$ in $100 \mathrm{~mL}$ distilled water. These solutions were added to one liter of glucose yeast (GY) medium immediately before pouring into Petri dishes, forming insoluble calcium phosphate. The isolates that formed visible clear halos around their colonies were considered phosphate solubilizers. 


\section{In vitro indolic compound production}

All isolates were grown in YEM broth. Optical density was used to control inoculum size $\left(10^{5}\right.$ $\left.10^{6} \mathrm{cfu} \mathrm{mL}^{-1}\right)$. Inocula were transferred $(100 \mathrm{~mL})$ to King B medium, which is the medium used to quantify indolic compound production, according to Glickmann \& Dessaux (1995). This method makes use of the Salkowski reagent $\left(12 \mathrm{~g} \mathrm{~L}^{-1} \mathrm{FeCl}_{3}+7.9 \mathrm{~mol} \mathrm{~L}^{-1}\right.$ $\mathrm{H}_{2} \mathrm{SO}_{4}$ ), and was used to quantify indole 3 acetic acid (IAA), indolepyruvic acid (IPyA), and indoleacetamide (IAM) production, which will be cited in the text collectively as indolic compounds.

\section{Anaerobiosis}

All isolates were tested for their growth capacity in an anaerobiosis chamber. The isolates were streaked on two media, YMA and Tiamine-biotine agar (TBA, Seldin et al., 1983) and incubated in anaerobiosis jars for seven days at $28^{\circ} \mathrm{C}$.

\section{Genotype characterization}

\section{Genotypic characterization by rep-PCR and RFLP of the nifH gene}

Bacterial total DNA was extracted as described by Giongo et al. (2007). Rep-PCR reactions were performed using enterobacterial repetitive intergenic consensus primers ERIC1-R (ATGTAAGCTCCTGGGGATTCAC) and ERIC-2 (AAGTAAGTGACTGGGGTGAGCG) (De Bruijn, 1992) and enterobacterial repetitive sequences BOX A1 primer (CTACGGCAAGGCGACGCTGACG, Versalovic et al., 1994). Reactions were performed in a PCR Express Temperature Cycling System (Thermo Hybaid) and the fragments visualized after electrophoresis on $1.0 \%$ UltraPure agarose gels (Invitrogen Life Technologies). A molecular size marker (1 Kb Plus DNA ladder, Gibco BRL) was run on all gels.

A template of 100 ng DNA was used in RFLP procedures. Selected primers PolF and PolR [TGCGAYCCSAARGCBGACTC and ATSGCCATCA TYTCRCCGGA, respectively (Poly et al., 2001)] were used to amplify a 360-bp region of nifH gene. PCR amplifications were carried out as described by Poly et al. (2001). For restriction enzyme cleavage, $10 \mu \mathrm{L}$ of each PCR product was directly used. The reaction enzyme mixture contained $1 \mathrm{X}$ restriction enzyme buffer and 1.25 U of restriction endonuclease. TaqI and HaeIII were selected for their specificity for the amplified nifH region. The PCR products were digested overnight. Digested DNA samples were analyzed by electrophoresis in a $30 \%$ polyacrylamide gel. The electrophoresis conditions were $5 \mathrm{~h}$ at $150 \mathrm{~V}$ in $1 \mathrm{X}$ Tris-borate-EDTA buffer at room temperature, followed by $30 \mathrm{~min}$ of silver nitrate staining. All fingerprint patterns were converted into a twodimensional binary matrix ( 1 , presence of a band; 0 , absence of a band) and analyzed using the Jaccard (J) coefficient, which does not consider the negative similarities. The matrix was analyzed using the NTSYS-PC package. UPGMA (Unweighted Pair Group Method with Arithmetic mean) algorithm was used to perform hierarchical cluster analysis and construct a dendrogram.

\section{Partial sequencing of the 16S rRNA gene}

PCR fragments obtained by the amplification of a $434 \mathrm{bp}$ DNA fragment corresponding to a region of the 16S rDNA gene of each isolate were sequenced. This region was amplified using primers U968 (AACGCGAAGAACCTTAC) and L1401 (CGGTGTGTACAAGACCC) (Felske et al., 1997). PCR reactions were performed in a $25 \mu \mathrm{L}$ volume, containing $50 \mathrm{ng}$ of DNA template, $1 \mathrm{U}$ of Taq DNA polymerase (Life Technologies), 1 X Taq DNA polymerase reaction buffer, $1.5 \mathrm{mmol} \mathrm{L}^{-1} \mathrm{MgCl}_{2}$, $200 \mathrm{mmol} \mathrm{L}^{-1}$ dNTPs (Life Technologies) and 10 pmoles of each primer. Amplification was carried out for 32 cycles as follows: one initial denaturation cycle at $95^{\circ} \mathrm{C}$ for $5 \mathrm{~min}, 30$ denaturation cycles for $45 \mathrm{~s}$ at $94{ }^{\circ} \mathrm{C}$, annealing for $45 \mathrm{~s}$ at $52{ }^{\circ} \mathrm{C}$, and extension for $45 \mathrm{~s}$ at $72^{\circ} \mathrm{C}$, and one final extension cycle for $5 \mathrm{~min}$ at $72^{\circ} \mathrm{C}$. Reactions were performed in a PCR Express Temperature Cycling System (Thermo Hybaid) and the fragments were visualized after electrophoresis at $80 \mathrm{~V}$ for $1 \mathrm{~h}$ on $1.5 \%$ agarose gel stained with ethidium bromide. A molecular size marker $(1 \mathrm{~Kb}$ plus DNA ladder, Gibco BRL) was run on all gels. Sequences of partial 16S rDNA genes were determined in both the forward and reverse directions with U986 and L1401 primers in the ACTGene Laboratory (Centro de Biotecnologia, UFRGS, RS, Brazil) using the automatic sequencer ABI-PRISM 3100 Genetic Analyzer (Applied Biosystems). Sequences were submitted to the GenBank database, using the program BLASTN (National Center for Biotechnology Information, http://www.ncbi.nlm.nih.gov/BLAST/). The nucleotide sequences of the two partial 16S rDNA segments (434 bp for both sequences) determined in this study were deposited in the GenBank database (Rp1p isolate labeled EF585402 and Rp2p isolate labeled EF585401).

\section{Plant growth promotion experiment}

Pure bacterial cultures were grown in TY medium at $28^{\circ} \mathrm{C}$ until they reached a final concentration of $10^{9} \mathrm{cfu} \mathrm{mL}^{-1}$. Seeds of $L$. albescens were surfacesterilized in $70 \%$ ethanol for $2 \mathrm{~min}$ and $1.2 \% \mathrm{Na}$ hypochlorite for $10 \mathrm{~min}$, and rinsed 10 times in sterile tap water. Pots $(500 \mathrm{~mL})$ filled with a sterile mixture of vermiculite and sand (1:1) were seeded with three seeds. After emergence, seedlings were thinned to one per pot and were grown in a growth chamber with $12 \mathrm{~h}$ of light at $25^{\circ} \mathrm{C}$. The experiment was conduced in a completely randomized design, with three replicates. Treatments consisted of inoculation with $1 \mathrm{~mL}$ of RP1p or RP2p bacterial culture or one $\mathrm{mL}$ of sterile TY medium, in the uninoculated control. Besides, each pot received $20 \mathrm{mg}$ of $\mathrm{N}$ as $\mathrm{NH}_{4} \mathrm{NO}_{3}$ 
and was irrigated with distilled water without micro or macronutrients. Forty days after sprouting, plants were harvested and dried to constant weight at $65^{\circ} \mathrm{C}$. Next, the dry weight was determined and the data subjected to ANOVA and Turkey's test $(p=0.05)$.

\section{RESULTS AND DISCUSSION}

\section{Genotypic characterization of the isolates by rep-PCR and RFLP of the nifH gene}

Aiming to identify some of the plant growthpromoting bacteria (PGPB) that inhabit the rhizoplane of $L$. albescens, small root pieces of plants cultivated in a sandy area of an experimental field in Alegrete, Rio Grande do Sul, Brazil, were collected. Five bacterial strains were randomly selected from this PGPB collection. These strains were genotypically characterized in electrophoretic profiles of amplification products using rep-PCR and RFLP methodologies. The RFLP analysis was based on a $360 \mathrm{bp}$ fragment of the nifH gene, which is one of the most important genes in the biological $\mathrm{N}_{2}$ fixation system and encodes the nitrogenase reductase protein (Mortenson, 1979). Although the existence of the nifH gene does not necessarily represent nitrogenase activity, as this enzyme is regulated at both pre- and posttranslational levels (Dean \& Jacobson, 1992), its presence in the genome is a good evidence that the bacterium is a nitrogen-fixer. The genotypic results obtained with the isolates (RP1p, RP1g, RP2p, RP2g, and RP3p) and the reference strains (Bradyrhizobium sp. SEMIA 928 and 938, Klebsiella sp., Enterobacter sp., Pseudomonas sp.) were used to construct a dendrogram (Figure 1). The dendrogram obtained indicated that in fact there were only two different isolates, RP1p and RP2p, and that both contained a nifH gene. The similarity of these bacteria with the

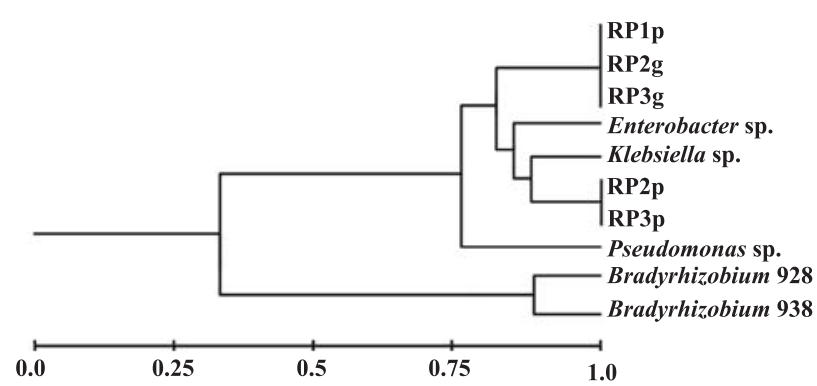

Figure 1. Dendrogram based on UPGMA cluster analysis with the NTSYS-PC program using repPCR and nifH-PCR-RFLP data obtained from L. albescens isolates (RP1p, RP2g, RP3g, RP2p, and RP3p) and strains used as control (Bradyrhizobium sp. SEMIA 928, Bradyrhizobium sp. SEMIA 938, Enterobacter sp., Pseudomonas sp., and Klebsiella sp.).
Bradyrhizobium reference strains SEMIA 928 and 938 was about $30 \%$ of nifH, differing about $30 \%$ from each other (Figure 1). For this reason, all following experiments were carried out with these two strains together with the reference strains.

\section{Identification of PGPB strains}

According to the sequence analysis of the $16 \mathrm{~S}$ rDNA partial sequences (434 bp) RP1p strain showed highly genetic similarity (95\% homology) with Enterobacter sp. PW4 (GenBank number DQ985288.1), and RP2p strain showed $95.2 \%$ of homology with Serratia sp. TCR (GenBank number EF070125.1). These results indicated that the strains RP1p and RP2p belong to the Enterobacteriaceae family that contains several $\mathrm{N}_{2}$-fixing organisms (Reinhardt et al., 2008). Although rhizosphere bacteria are largely represented by species of Pseudomonas and Bacillus genera, some authors have found bacteria belonging to the Enterobacteriaceae family including Serratia, Pantoea and Enterobacter strains in the rhizoplane of leguminous plants (Bent, 2006).

\section{Phenotypic characterization of the isolates}

The capacity to use different carbon sources of strains RP1p and RP2p was evaluated (Table1) since these data can permit a greater insight into the ecology and metabolism of microbial species in the rhizosphere. Strain RP1p was able to utilize 10 out of $14 \mathrm{C}$ sources evaluated while RP2p utilized nine $\mathrm{C}$ sources. Both strains were unable to utilize either Larabinose or lactose as sole $\mathrm{C}$ source. Although glucose is the preferred $\mathrm{C}$ source for diazotrophic strains of Enterobacteriaceae, bacteria from this family vary a lot in terms of $\mathrm{C}$ source utilization (Cannon et al., 1974). Strains belonging to Pseudomonas, one of the most well-known PGPB genera, are especially wellsuited to the rhizosphere because they are able to use a wide variety of $\mathrm{C}$ sources as nutrients (Misko \& Germida, 2002). PGPBs that are capable of a wide range of metabolic activities and able to utilize a wide range of $\mathrm{C}$ and energy sources may be well-suited in the rhizosphere (Dunfield \& Germida, 2001; Misko \& Germida, 2002). This characteristic can be useful not only to observe if isolates can utilize a particular $\mathrm{C}$ source, but whether the strains are metabolically similar. Understanding the metabolic profile of strains could help to understand how bacteria can compete and survive in the root environment.

Based on the experiments of phenotypic characterization, the two isolates correspond to Gramnegative, rod-shaped, motile, and facultative anaerobic bacteria. Under electron microscopy cells are often observed in pairs when grown on YMA (Figure 2). The two isolates were very fast-growing, forming convex, white, single, circular and mucoid colonies, (diameter of $3-4 \mathrm{~mm}$ ) within $24 \mathrm{~h}$ of incubation, at $28^{\circ} \mathrm{C}$ on YMA. These findings corroborate with the results 
Table 1. Morphological, physiological and biochemical characteristics of the strains isolated from the rhizoplane of $L$. albescens plants

\begin{tabular}{|c|c|c|c|}
\hline \multirow{2}{*}{\multicolumn{2}{|c|}{ Characteristic }} & \multicolumn{2}{|c|}{ Strain } \\
\hline & & RP1p & RP2p \\
\hline \multicolumn{2}{|c|}{ Gram staining } & - & - \\
\hline \multicolumn{2}{|c|}{ Congo red utilization } & - & - \\
\hline \multirow{7}{*}{ 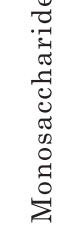 } & L-arabinose & - & - \\
\hline & D-fructose & + & + \\
\hline & D-galactose & + & + \\
\hline & D-glucose & + & + \\
\hline & D-mannose & + & + \\
\hline & Rhamnose & + & - \\
\hline & D-xylose & + & - \\
\hline \multirow{3}{*}{ 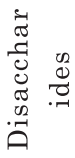 } & Lactose & - & - \\
\hline & Maltose & + & - \\
\hline & Sucrose & + & + \\
\hline \multirow{4}{*}{ 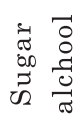 } & Glycerol & + & + \\
\hline & Inositol & - & + \\
\hline & Mannitol & + & + \\
\hline & Sorbitol & - & + \\
\hline \multirow{5}{*}{\multicolumn{2}{|c|}{$\begin{array}{l}0.5 \% \mathrm{NaCl} \\
1 \% \mathrm{NaCl} \\
2 \% \mathrm{NaCl} \\
3 \% \mathrm{NaCl} \\
4 \% \mathrm{NaCl}\end{array}$}} & + & + \\
\hline & & + & + \\
\hline & & + & + \\
\hline & & + & + \\
\hline & & - & - \\
\hline \multicolumn{2}{|c|}{ Siderophore production } & + & + \\
\hline \multicolumn{2}{|c|}{ Indolic compound production } & + & + \\
\hline \multicolumn{2}{|c|}{ Phosphate solubilization } & - & - \\
\hline \multicolumn{2}{|c|}{ Anaerobiosis } & + & + \\
\hline \multicolumn{2}{|c|}{ Growth at $40^{\circ} \mathrm{C}$} & + & + \\
\hline \multicolumn{2}{|c|}{ Growth at $\mathrm{pH} 4$} & + & + \\
\hline \multicolumn{2}{|c|}{ Growth at $\mathrm{pH} 10$} & + & + \\
\hline \multicolumn{2}{|c|}{ Growth rate } & very fast & very fast \\
\hline
\end{tabular}

obtained by the partial sequencing of $16 \mathrm{~S}$ rRNA that classified the bacteria as belonging to the genera Enterobacter and Serratia.

The sensitivity of the isolates to extreme $\mathrm{pH}$, high salinity and high temperatures was also analyzed (Table 1). While $28^{\circ} \mathrm{C}$ is the optimum temperature for the growth of many soil strains, the two isolates were able to grow at temperatures as high as $40^{\circ} \mathrm{C}$. Although in vitro temperature selection is not considered a promising approach for field applications (Hungria \& Vargas, 2000), this high temperature tolerance can be useful for the purpose of isolating competitive PGPR in oscillating temperature fields. Both isolates were also able to grow in the presence of high $(2-3 \% \mathrm{w} / \mathrm{v}) \mathrm{NaCl}$ concentrations. This result indicates that these bacteria could be potential candidates for applications in high-salinity soils.

Extreme $\mathrm{pH}$ values may be one of the major limiting factors for the presence of microorganisms in soils (Brockwell et al., 1991). RP1p and RP2p strains were able to grow in $\mathrm{pH}$ ranging from 4 to 10 . This indicates that these isolates could also be strong candidates for the improvement of highly alkaline or (a)

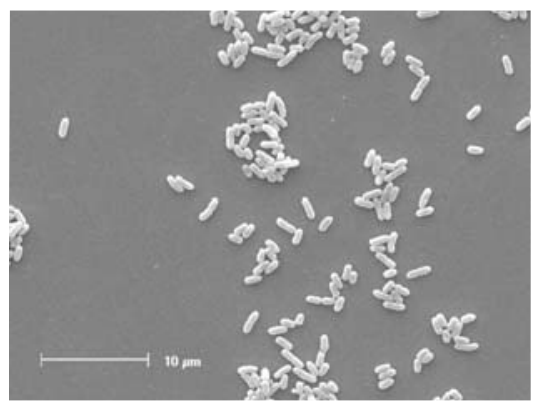

(b)

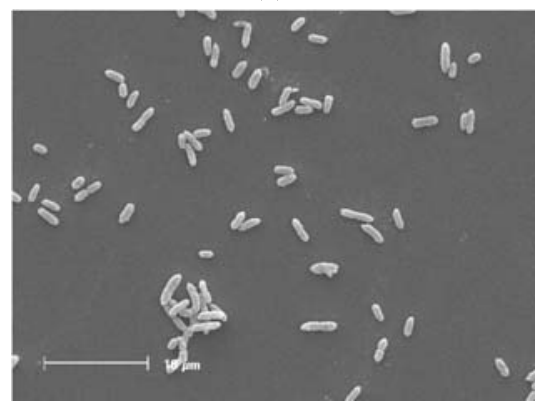

Figure 2. Scanning electron microscopy of vegetative cells of strain RP1p (a) and RP2p (b) shows frequent occurrence in pairs. Bars $=10 \mu \mathrm{m}$.

acidic soil, as is the soil in Alegrete, where the $\mathrm{pH}$ ranges from 4.5 to 5.0. The two bacterial isolates were therefore capable of producing a huge amount of mucous and exopolysaccharides (data not shown). These compounds are probably a protection against desiccation and favor growth at extreme temperatures, salinity and $\mathrm{pH}$ values.

Various soil microorganisms live in the plant rhizosphere and rhizoplane due to the rich nutrient availability. Although bacteria such as Rhizobium, Azotobacter and Azospirillum enhance plant growth as a result of their ability to fix- $\mathrm{N}_{2}$, bacteria with mechanisms such as phytohormone production in the rhizosphere and other PGP activities can contribute to improve the ability of the host plant to survive in extreme environments (Glick, 1995; Bashan \& Holgin, 1998). RP1p and RP2p strains produced 85.0 and $53.0 \mu \mathrm{g} \mathrm{mL}^{-1}$ of indolic compounds in vitro, respectively. Mirza et al. (2001) showed that indolic compound production can vary among different species and strains and is also influenced by culture condition, growth stage and availability of the substrate. Barazani \& Friedman (1999) reported PGPR that were able to secrete up to $13.5 \mu \mathrm{g} \mathrm{mL}^{-1}$ of indolic compounds. Strains of Enterobacter sp. isolated from the rhizosphere of sugarcane produced about $2.21 \mu \mathrm{g} \mathrm{mL}-1$ of indolic compounds in vitro when tryptophan was added to the medium (Mirza et al., 2001). The comparison with the above results allowed us to conclude that the two PGPB isolated in this study are very efficient indolic compound producers. 
Another PGP feature is the production of siderophores that may influence plant growth by binding to the available form of iron $\left(\mathrm{Fe}^{3+}\right)$ in the rhizosphere. Through this process, $\mathrm{Fe}$ is made unavailable to the phytopathogens. Consequently, siderophores protect the plant health (Siddiqui, 2005). As observed with indolic compounds, both isolates produced a large amount of siderophores on medium with CAS. Press et al. (2001) reported that the catechol siderophore biosynthesis genes of Serratia marcescens are associated with resistance of cucumber against anthracnose. The only characteristic of all PGPB features tested in this study that was not observed in the two isolated strains was phosphate solubilization. This characteristic was absent in the reference strains as well.

\section{Growth-promoting effect of bacterial treatment of Lupinus plants}

In order to test the effective contribution to plant growth, the two isolates were used for in vivo experiment. A significant increase in dry matter weight was recorded in L. albescens plants inoculated with $\mathrm{RP} 1 \mathrm{p}$ and $\mathrm{RP} 2 \mathrm{p}$. Inoculation with these two bacteria increased 75 and $81 \%$, respectively, the dry matter plant contents when compared with the uninoculated control (Figure 3). The observed growth promotion and increase in dry matter contents in response to PGPR inoculation could be explained on the basis of the abilities identified in these two isolates, including the production of plant growth regulators, such as indolic compounds.

Since the benefits from the plant growth-promoting bacteria could be synergistic (Ahmad et al., 2008), further studies on the effects of RP1p and RP2p isolates on plant growth in sandy areas will be necessary to evaluate the utility of this extra tool to recover such degraded fields.

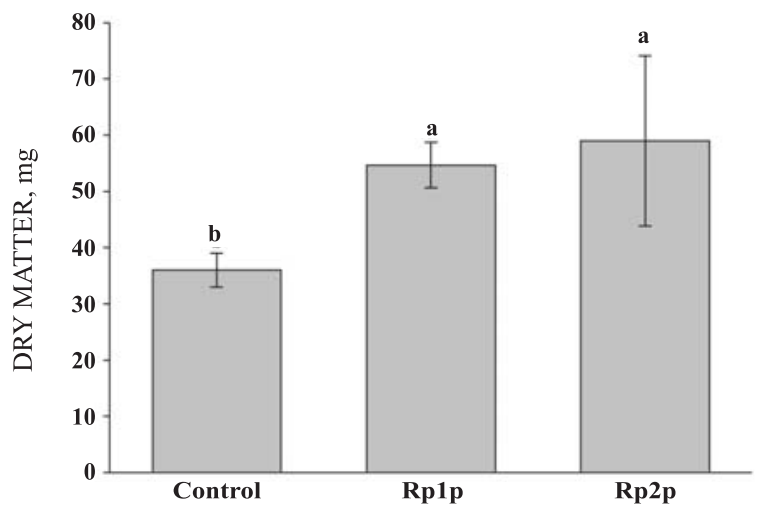

Figure 3. Effect of inoculation of plant-growthpromoting bacteria on $L$. albescens plants, 40 days after emergence. Different letters indicate significant values at $p=0.05$ in the Tukey test.

\section{CONCLUSION}

Two bacteria with plant growth-promoting abilities and carrying the nifH gene were isolated from the rhizoplane of $L$. albencens where a significant increase in the dry matter production of the analyzed plants was observed in comparison with non-inoculated plants.

\section{ACKNOWLEDGEMENTS}

The authors are grateful to Eliane V. Bangel from the Fundação Estadual de Pesquisa Agropecuária (FEPAGRO) for providing the Bradyrhizobium reference strains and to Dr. G. Pasquali (Centro de Biotecnologia - UFRGS, RS, Brazil) for sequencing facilities. This research was supported by grants and fellowships of the Conselho Nacional de Desenvolvimento Científico e Tecnológico (CNPq/Brazil) and Fundação de Amparo à Pesquisa do Estado do Rio Grande do Sul (FAPERGS/Brazil).

\section{LITERATURE CITED}

AHMAD, F.; AHMAD, I. \& KHAN, M.S. Screening of freeliving rhizospheric bacteria for their multiple plant growth-promoting activities. Microbiol. Res., 163:173-181, 2008.

BARAZANI, O. Z. \& FRIEDMAN, J. Is IAA the major root growth factor secreted from plant-growth-mediating bacteria? J. Chem. Ecol., 25:2397-2406, 1999.

BAREA, J.M.; POZO, M.J.; AZCON, R. \& AZCON-AGUILAR, C. Microbial co-operation in the rhizosphere. J. Exper. Bot., 56:1761-1778, 2005.

BASHAN, Y. \& HOLGUIN, G. Proposal for the division of plant growth-promoting rhizobacteria into two classifications: Biocontrol-PGPB (plant growth-promoting bacteria) and PGPB. Soil Biol. Biochem., 30:1225-1228, 1998.

BENT, E. Induced systemic resistance mediated by plant growth-promoting rhizobacteria (PGPR) and fungi (PGPF). In: TUZUN, S. \& BENT, E., eds. Multigenic and induced systemic resistance in plants. New York, Springer, 2006. p.225-258.

BORGES, F.P.; WILTUSCHNIG, R.C.; TASCA, T. \& DE CARLI, G.A. Scanning electron microscopy study of Tritrichimonas augusta. Parasitol. Res., 94:158-161, 2004.

BROCKWELL, J.; PILKA, A. \& HOLLIDAY, R.A. Soil pH is a major determinant of the numbers of naturally occurring Rhizobium meliloti in non-cultivated soils of New South Wales. Austr. J. Exper. Agric., 31:211-219, 1991. 
BROWN, C.M. \& DILWORTH, M.J. Ammonia assimilation by Rhizobium cultures and bacteroids. J. Gen. Microbiol., 86:39-48, 1975 .

CANNON, F.C.; DIXON, R.A.; POSTGATE, J.R. \& PRIMROSE, S.B. Chromosomal integration of Klebsiella $\mathrm{N}$ fixation genes in Escherichia coli. J. Gen. Microbiol., 80:227-239, 1974.

DEAN, D.R. \& JACOBSON, M.R. Biochemical genetics of nitrogenase. In: STACY, G.; BURRIS, R.H. \& EVANS, H.J., eds. Biological nitrogen fixation. New York, Chapman and Hall, 1992. p.763-834.

DE BRUIJN, F.J. Use of repetitive extragenic palindromic and enterobacterial repetitive intergenic consensus sequences and the polymerase chain reaction to fingerprint the genomes of Rhizobium meliloti isolates and other soil bacteria. Appl. Environ. Microbiol., 58:21802187,1992

DOETSCH, R.N. Determinative methods of light microscopy. In: GERDHARDT, P.; MURRAY, R.G.E.; COSTILOW, R.N.; NESTER, E.W.; WOOD, W.A.; KRIEG, N.R. \& PHILLIPS, G.B., eds. Manual of methods for general bacteriology. Washington, American Society for Microbiology, 1981. p.21-33.

DUNFIELD, K.E. \& GERMIDA, J.J. Diversity of bacterial communities in the rhizosphere and root interior of fieldgrown genetically modified Brassica napus. Microbiol. Ecol., 38:1-9, 2001.

FELSKE, A.; RHEIMS, H. \& WOLTERINK, A. Ribosome analysis reveals prominent activity of an uncultured member of the class Actinobacteria in grassland soils. Microbiology, 143:2983-2989, 1997.

FRED, E.B. \& WAKSMAN, S.A. Laboratory manual of general microbiology - With special reference to the microorganisms of the soil. New York, McGraw-Hill Book Company, 1928.145p.

GIONGO, A.; PASSAGLIA, L.M.P.; FREIRE, J.R.J. \& SÁ, E.L.S. Genetic diversity and symbiotic efficiency of population of rhizobia of Phaseolus vulgaris L. in Brazil. Biol. Fert. Soils, 43:593-598, 2007.

GLICK, B.R. The enhancement of plant growth by free-living bacteria. Can. J. Microbiol., 41:109-114, 1995.

GLICKMANN, E. \& DESSAUX, Y. A critical examination of the specificity of the Salkowski Reagent for indolic compounds produced by phytopathogenic bacteria. Appl. Environ. Microbiol., 61:793-796, 1995.

HAN, J.; SUN, L.; DONG, X.; CAI, Z.; SUN, X.; YANG, H.; WANG, Y. \& SONG, W. Characterization of a novel plant growth-promoting bacteria strain Delftia tsuruhatensis HR4 both as a diazotroph and a potential biocontrol agent against various plant pathogens. Syst. Appl. Microbiol., 28:66-76, 2005.

HUNGRIA, M. \& VARGAS, M.A.T. Environmental factors affecting $\mathrm{N}_{2}$ fixation in grain legumes in the tropics, with an emphasis on Brazil. Field Crops Res., 65:151-164, 2000.
KLOEPPER, J.W.; LEONG, J.; TEINTZE, M. \& SCRHORTH, M.N. Enhanced plant growth by siderophores produced by plant growth-promoting rhizobacteria. Nature, 286:885-886, 1980.

MAC FADDIN, J.F. Biochemical tests for identification of medical bacteria. 3.ed. Baltimore, Lippincott Williams \& Wilkins, 2000. 912p.

MIRZA, M.S.; AHMAD, W.; LATIF, F.; HAURAT, J.; BALLY, R.; NORMAND, P. \& MALIK, K.A. Isolation, partial characterization, and the effect of plant growth-promoting bacteria (PGPB) on micro-propagated sugarcane in vitro. Plant Soil, 237:47-54, 2001.

MISKO, A.L. \& GERMIDA, J.J. Taxonomic and functional diversity of pseudomonads isolated from the roots of fieldgrown canola. Microbiol. Ecol., 42:399-407, 2002.

MORTENSON, L. Structure and function of nitrogenase. Ann. Rev. Biochem., 48:387-418, 1979.

MOSCHETTI, G.; PELUSO, A.L.; PROTOPAPA, A.; ANASTASIO, M.; PEPE, O. \& DEFEZ, R. Use of nodulation pattern, stress tolerance, nodC gene amplification, RAPD-PCR and RFLP-16S rDNA analysis to discriminate genotypes of Rhizobium leguminosarum biovar viciae. Syst. Appl. Microbiol., 28:619-631, 2005.

POLY, F.; MONROZIER, L.J. \& BALLY, R. Improvement in RFLP procedure to study the community of $\mathrm{N}$ fixers in soil through the diversity of nifH gene. Res. Microbiol., 152:95-103, 2001.

PRESS, C.M.; LOPER, J.E. \& KLOEPPER, J.W. Role of iron in rhizobacteria-mediated induced systemic resistance of cucumber. Phytopathology, 91:593-598, 2001.

REINHARDT, E.L.; RAMOS, P.L.; MANFIO, G.P.; BARBOSA, H.R.; PAVAN, C. \& MOREIRA-FILHO, C.A. Molecular characterization of nitrogen-fixing bacteria isolated from Brazilian agricultural plants in São Paulo State. Braz. J. Microbiol., 39:414-422, 2008.

SCHUMACHER, V.M. "Deserto de Alegrete" - Florestas, uma alternativa de controle? Viçosa, MG, Sociedade Brasileira de Recuperação de Áreas Degradadas/Universidade Federal de Viçosa, 2000. p.21-23.

SCHWYN, B. \& NEILANDS, J.B. Universal chemical assay for the detection and determination of siderophores. Anal. Biochem., 160:47-56, 1987.

SELDIN, L.; VAN ELSAS, J.D. \& PENIDO, E.G.C. Bacillus nitrogen fixers from Brazilian soils. Plant Soil, 70:243$255,1983$.

SIDDIQUI, Z.A. PGPR: Prospective biocontrol agents of plant pathogens. In: PGPR: Biocontrol and biofertilization. Netherlands, Springer, 2005. p.111-142.

SOLANO, R.B.; LA IGLESIA, M.T.P.; PROBANZA, A. \& GARCIA, J.A.L. Screening for PGPR to improve growth of Cistus ladanifer seedlings for reforestation of degraded Mediterranean ecosystems. Plant Soil, 287:59-68, 2006. 
SOMASEGARAN, P. \& HOBEN, J.H. Handbook for Rhizobia: Methods in legume-Rhizobium technology. New York, Springer-Verlag, 1994. 450p.

SOUTO, J.J. Deserto, uma ameaça? Porto Alegre, Secretaria da Agricultura, 1984.169p.

STROSCHEIN, M.R.D. Caracterização de bactéria fixadora de nitrogênio em Lupinus albescens. Santa Maria, Universidade Federal de Santa Maria, 2007. 83p. (Tese de Mestrado)
SYLVESTER-BRADLEY, R.; ASAKAWA, N.; LA TORRACA, S.; MAGALHÃES, F.M.M.; OLIVEIRA, L. \& PEREIRA, R.M. Levantamento quantitativo de microrganismos solubilizadores de fosfatos na rizosfera de gramíneas e leguminosas forrageiras na Amazônia. Acta Amaz., 12:15$22,1982$.

VERSALOVIC, J.; SCHNEIDER, M.; DE BRUIJN, F.J. \& LUPSKI, J.R. Genomic fingerprinting of bacteria using repetitive sequence-based polymerase chain reaction. Methods Molec. Cel. Biol., 5:25-40, 1994. 